\title{
WATERSHED - Android Application for the Mineral Waters Classification
}

\author{
LAVINIA MISAIL A ${ }^{1,2}$, FLORIN MARIAN NEDEFF ${ }^{1}$, NARCIS BARSAN ${ }^{1 *}$, IOAN GABRIEL SANDU ${ }^{3,4}$, LUMINITA GROSU $^{1}$, \\ OANA-IRINA PATRICIU1', LUCIAN GAVRILA1, ADRIANA-LUMINITA FINARU1* \\ ${ }^{1}$ Vasile Alecsandri University of Bacau, Faculty of Engineering, Calea Marasesti 156, 600115 Bacau, Romania \\ 2Dimitrie Ghika Technical College, Comanesti, Bacau County, 605200, Comanesti, Romania \\ ${ }^{3}$ Gheorghe Asachi Technical University, Materials Science and Engineering Faculty, 53A D. Mangeron Blvd., 700050 lasi, Romania \\ ${ }^{4}$ Romania Inventors Forum, 3 Sf. Petru Movila St., BI. L11, Sc. A, et. III, Ap. 3, 700089, Iasi, Romania
}

\begin{abstract}
Water classification based on mineral content is useful to determine the curative properties of each type. The water type is determined accordingly the parameter followed, like as: physical, chemical, microbiological, pharmacological, physiological and clinic. This paper presents a study of the main types of mineral waters based on specific criteria of classification applied to the mineral water springs found in the treatment resort, Slanic-Moldova. The concept of Stuyfzand's water classification was applied to build an Android application - named Watershed, using a block-based encryption program, MIT App Inventor. This program classifies the mineral water source by chemical composition and its location on the map using the Google Maps mapping system. By synchronization with the Google Maps online service, a map of mineral water springs at source as well as a capture can be created.
\end{abstract}

Keywords: Android application, chemical analysis, mineral water, type, therapy, spring, sustainability

Mineral water is considered to be natural water that comes from an underground source or an artificial source (drilled source) and has a variable content of salts, gases, minerals, radioactive substances that gives it therapeutic properties. The origin of the mineral waters is related to the presence of some deep downthrows, but also to the existence of the volcanic mountainous relief and to the area of important deposits of oil, coal, methane and salt. In the past, the name of mineral water was attributed to all underground or superficial waters that could be used for therapeutic purposes. In recent years, mineral waters for therapeutic purposes have been given the name of curative waters. But they are also used in the soft drinks industry [1].

Passing through successive layers of soil, the water cleans and dissolves minerals and soluble salts, organic and bioactive substances extremely beneficial to the body $[2,3]$.

Data from the National Mineral Water Society (SNAM) shows that Romania currently has over $60 \%$ of Europe's mineral water reserves and we only operate $20 \%$. In terms of volume, the total market of bottled water in Romania reaches about 11.3 million hectoliters, or about $0.16 \mathrm{~L}$ per day per person [4].

Numerous clinical studies have investigated the role and effects of mineral water consumption demonstrating certain curative properties of mineral water. Nutritionists say that carbonated mineral waters generally have a higher concentration of dry residue and chemical compounds (calcium, sodium) and are not recommended for people suffering from kidney or high blood pressure [3].

Examinations that are performed according to scientifically recognized methods $[5,6]$ are tailored to the natural mineral water's own characteristics and effects on the human body such as diuresis, gastric and intestinal functions, and mineral deficit compensation.

Determination of the coherence and consistency of a considerable number of clinical observations may, where appropriate, replace the above-mentioned examinations.
Clinical examinations may, in certain cases, replace the certain examinations provided that the same results are obtained [2, 3].

The mineral waters from Slanic-Moldova have a complex composition (carbonate, bicarbonate, slightly sulphurous, chloride, sodium, hypertonic, hypotonic) that has been studied by many Romanian scientists or doctors (D. Hurmuzescu, E. Severin, A. Teohari, G. Tudoran, C. Baltaceanu, geologist St. Cantuniari, Romulus Busnea), who highlighted their numberless curative properties [7, 8].

Dr. G. Tudoran concluded that the waters of Slanic are a happy association, available to the doctors to treat most of the diseases of the stomach, intestines, liver, nutrition diseases in Slanic are springs for all diseases of the digestive system, as it does not exist in any resort in the world [7].

The waters of the springs in Slanic Moldova (springs 1, 3 and 4) received the silver medal at the International Balneology Exhibition in Frankfurt am Main, in 1881, the Golden Medal at the Vienna Specialized Exhibition, 1883 and the world's supreme recognition, with the Gold Medal at the Universal Paris Exhibition, 1900 [1].

The first chemical analyses of these springs began in 1852 and in 1877 were set up the first treatment establishment [8].

The classification of mineral waters according to the weight of certain minerals in their composition is useful for identifying the curative properties of each type of mineral water. The chemical elements in mineral waters act synergistically or antagonistically on the body, the actions cumulate or cancel each other, the therapeutic result representing the sum of the action of all the constituent elements. In this context the evaluation of the environmental medium quality is also a very important aspect $[9,10]$.

The purpose of this study is to create an instrument which can easily classify the type of mineral water, place it on a the map accordingly to its geographical coordinates, and allow the researcher to create its own map for the

\footnotetext{
* email: narcis.barsan@ub.ro; adrianaf@ub.ro
} 
studied water spring and/or add them to the geographic map of the area, to simplify their recommendation for both consumptions and for the treatment of various diseases.

\section{Experimental part}

Mineral water dataset

Geographical location

Slanic Moldova is situated $18 \mathrm{~km}$ from Tg. Ocna, in the north-eastern part of Bacau County, Romania, on the valley of the Slanic River, in a depression surrounded by coniferous and deciduous forests. The Slanic River, with a length of 25 $\mathrm{km}$, springs from Sandru Mare mountain and lowers a difference of $500 \mathrm{~m}$ up to its flow into the Trotuo River in the neighboring of town Tg. Ocna. The main mountain peaks that separate Slanic Valley north from Dofteana Valley and south from Oituz Valley are the peaks Dobru, Cerbu and Pufu. In the Slanic Valley, there are over 20 springs of mineral waters. They are spread over a distance of about two kilometers, from the confluence of Slanic River with Slanicel River (550 $\mathrm{m}$ altitude) and to the confluence of Slanic River with the Scari-oara brook, grouped by 3-4 or isolated 50-150 $\mathrm{m}$ apart. Most springs are located on the right bank of the Slanic River and are named accordingly to the place or sequence they have been discovered.

Therapeutic indications of mineral waters from SlanicMoldova:

Digestive system disorders (chronic hypoacid and hyperacid gastritis, gastric and duodenal ulcers at least three months after the painful period, states after the operated stomach, chronic non-specific colitis); hepatobiliary disorders (biliary dyskinesia, chronic noncalculating or calculus cholecystitis, conditions after operative liver or cholecystectomy); respiratory tract disorders (allergic asthma, chronic tracheobronchitis, bronchiectasis, pulmonary emphysema, chronic rhinosinusitis); metabolic and nutritional disorders (diabetes, mild and moderate forms, obesity); kidney and urinary disorders; peripheral neurological disorders; posttraumatic conditions; associated diseases (degenerative or articular rheumatism, cardiovascular, endocrine, gynecological, occupational, attenuated neurosis) [11-14].
Definition of the mineral water according with 2009/54/ EC Directive [15]

Natural mineral water means microbiologically wholesome water, within the meaning of Article 5, originating in an underground water table or deposit and emerging from a spring tapped at one or more natural or bore exits.

Natural mineral water can be clearly distinguished from ordinary drinking water:

(a) by its nature, which is characterized by its mineral content, trace elements or other constituents and, where appropriate, by certain effects;

(b) by its original state, both characteristics having been preserved intact because of the underground origin of such water, which has been protected from all risk of pollution.

\section{The concentration of the ions into the water}

According to the Directive 2009/54/EC of the European Parliament and of the Council of 18] une 2009 [15] on the exploitation and marketing of natural mineral waters, the mineral waters can be classified accordingly with the concentration of the ions [ $\left.\mathrm{mg}^{\mathrm{L}} \mathrm{L}^{-1}\right]$ ( table 1 ).

\section{Water model according to Stuyfzand's water classification} [16]

The water model proposed by Stuyfzand is a complex system of classification (fig. 1), which allows classifying almost 7128 types of waters according to their chemical characteristics, even if many water types do not exist in nature, which reduces the total number to a few hundred.

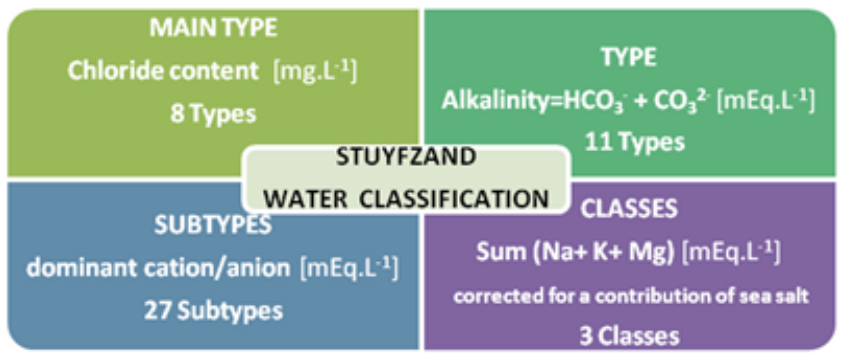

Fig.1. Stuyfzand Water Classification

Table 1

THE CONCENTRATION OF IONS IN WATER [mg..-1] [15]

\begin{tabular}{|c|c|}
\hline Category & Criteria \\
\hline Low mineral content & Mineral salt content, calculated as a fixed residue, not greater than $500 \mathrm{mg} . \mathrm{L}^{-1}$ \\
\hline Very low mineral content & Mineral salt content, calculated as a fixed residue, not greater than $50 \mathrm{mg} \cdot \mathrm{L}^{-1}$ \\
\hline Rich in mineral salt & Mineral salt content, calculated as a fixed residue, greater than $1500 \mathrm{mg}^{-1}$ \\
\hline Contains bicarbonate & Bicarbonate content greater than $600 \mathrm{mg}^{-1}$ \\
\hline Contains sulfate & Sulfate content greater than $200 \mathrm{mg}^{-1} \mathrm{-l}^{-1}$ \\
\hline Contains chloride & Chloride content greater than $200 \mathrm{mg} \cdot \mathrm{L}^{-1}$ \\
\hline Contains calcium & Calcium content greater than $150 \mathrm{mg} \mathrm{L}^{-1}$ \\
\hline Contains magnesium & Magnesium content greater than $50 \mathrm{mg} \cdot \mathrm{L}^{-1}$ \\
\hline Contains fluoride & Fluoride content greater than $1 \mathrm{mg} \mathrm{L}^{-1}$ \\
\hline Contains iron & Bivalent iron content greater than $1 \mathrm{mg} \cdot \mathrm{L}^{-1}$ \\
\hline Acidic & Free carbon dioxide content greater than $250 \mathrm{mg} \cdot \mathrm{L}^{-1}$ \\
\hline Contains sodium & Sodium content greater than $200 \mathrm{mg} \cdot \mathrm{L}^{-1}$ \\
\hline Suitable for preparation of infant food & - \\
\hline Suitable for a low sodium diet & Sodium content less than $20 \mathrm{mg} \cdot \mathrm{L}^{-1}$ \\
\hline Maybe laxative / diuretic & - \\
\hline
\end{tabular}


The Stuyfzand water classification (Stuyfzand, 1986, 1993), based on the most important chemical characteristics of water, includes the following subdivision levels: main types, types, subtypes, and classes. To determine the primary type (8 main types), the chloride content is used as a parameter. The type is determined by alkalinity (11 types). The subtype is determined based on the dominant cations and anions content (27 subtypes). Finally, classification in a class is based on the sum of $\mathrm{Na}$, $\mathrm{K}$, and $\mathrm{Mg}$ in $\mathrm{mEq} . \mathrm{L}^{-1}$ corrected for the contribution of sea salt (3 classes) [16].

\section{Main type}

The main types of water are classified into eight categories depending on the concentration of the anion $\mathrm{Cl}^{-}$ [mg. $\mathrm{L}^{-1}$. The content in chloride determines the main type, which is assigned a code number, as shown in table 2.

Table 2

MAIN TYPES OF WATER ON THE BASIS OF ClCONCENTRATION [16]

\begin{tabular}{|l|c|c|}
\hline \multicolumn{1}{|c|}{ Main type } & Code & $\mathrm{Cr}\left[\mathrm{mg} \cdot \mathrm{L}^{-1}\right]$ \\
\hline very oligohaline & $\mathrm{G}$ & $<5$ \\
\hline oligohaline & $\mathrm{g}$ & $5-30$ \\
\hline fresh & $\mathrm{F}$ & $30-150$ \\
\hline fresh-brackish & $\mathrm{f}$ & $150-300$ \\
\hline brackish & $\mathrm{B}$ & $300-10^{3}$ \\
\hline brackish-salt & $\mathrm{b}$ & $10^{3}-10^{4}$ \\
\hline salt & $\mathrm{S}$ & $10^{4}-2.10^{4}$ \\
\hline hypersaline & $\mathrm{H}$ & $>2.10^{4}$ \\
\hline
\end{tabular}

Type

Each major type is divided into a maximum of 11 categories based on alkalinity (table 3). The upper limit of each type is defined as follows:

$$
\text { Upper boundary type } x=2 x
$$

in $\mathrm{mEq} \cdot \mathrm{L}^{-1}$, where $\mathrm{x}$ is an integer between -1 and 9 .

The alkalinity of water is due to the presence of bicarbonates, carbonates and hydroxides (more rarely phosphates and silicates), salts with basic hydrolysis, expressed in Eg. $\mathrm{L}^{-1}$ and also corresponds to the temporary hardness of water.
Table 3

SUBDIVISION OF MAIN TYPES INTO TYPES ACCORDING TO ALKALINITY [14]

\begin{tabular}{|c|l|c|c|}
\hline No. & \multicolumn{1}{|c|}{ Type } & $\begin{array}{c}\text { Alkalinity } \\
{\left[\mathrm{mEq} \cdot \mathrm{L}^{-1}\right]}\end{array}$ & Code \\
\hline-1. & very low & $\kappa^{1 / 2}$ & $*$ \\
\hline 0 & low & $1 / 2-1$ & 0 \\
\hline 1. & moderately low & $1-2$ & 1 \\
\hline 2. & moderate & $2-4$ & 2 \\
\hline 3. & moderately high & $4-8$ & 3 \\
\hline 4. & high & $8-16$ & 4 \\
\hline 5. & very high & $16-32$ & 5 \\
\hline 6. & extremely high & $32-64$ & 6 \\
\hline 7. & extremely high & $64-128$ & 7 \\
\hline 8. & extremely high & $128-256$ & 8 \\
\hline 9. & extremely high & $\geq 256$ & 9 \\
\hline
\end{tabular}

Alkalinity is defined as the amount of hard acid. $\mathrm{L}^{-1}$ required to reach a $p H$ close to 4.5 . The majority of natural waters have $4.5 \leq \mathrm{pH}$ of $\leq 9.5$.

$$
\text { Alkalinity }=\mathrm{HCO}_{3}^{-}+\mathrm{CO}_{3}{ }^{2-}\left[\mathrm{mEq} \cdot \mathrm{L}^{-1}\right]
$$

\section{Subtypes}

It is determined by the preponderate cations and anions [mEq. $\mathrm{L}^{-1}$ in the ion balance. First, it is determined the dominant ion of each family, cation or anion and then the ion or pair of dominant ions in each family. The dominant ions are positioned at the vertex of two triangles, one for cations and one for anions, in descending order of their concentration. The grouping method is interesting because it allows the diversification of the classification. The term mixed water is assigned to those waters for which the concentration of an anion does not exceed $50 \%$ of the sum of the anions. The theoretical number of water subtypes is $9 \times 6=54$. So far only 27 have been discovered.

\section{Classes}

Each subtype is subdivided into 3 classes (table 4) according to a new parameter: the sum of $\mathrm{Na}, \mathrm{K}$ and $\mathrm{Mg}$ in $\mathrm{mEq} \cdot \mathrm{L}^{-1}$, corrected for a contribution of sea salt:

$(\mathrm{Na}+\mathrm{K}+\mathrm{Mg})$ corr. $=(\mathrm{Na}+\mathrm{K}+\mathrm{Mg})$ measured $-1.0716 \mathrm{Cl}$

\begin{tabular}{|c|c|c|}
\hline Class & Code & Condition for $(\mathrm{Na}+\mathrm{K}+\mathrm{Mg})\left[\mathrm{mEq}-\mathrm{L}^{-1}\right]$ \\
\hline$(\mathrm{Na}+\mathrm{K}+\mathrm{Mg})$ deficit $^{1}$ & - & $<1 / 2 \mathrm{Cl} \mid$ and $<1,5(\Sigma \mathrm{K}-\Sigma \mathrm{A})$ \\
\hline$(\mathrm{Na}+\mathrm{K}+\mathrm{Mg})$ equilibrium ${ }^{2}$ & . & $\geq 1 / 2 \mathrm{Cl}$ and $\leq 1 / 2 \mathrm{Cl}$ and $\Delta S$ \\
\hline$(\mathrm{Na}+\mathrm{K}+\mathrm{Mg})$ surplus ${ }^{3}$ & + & $>1 / 2 \mathrm{Cl} \mid>1,5(2 \mathrm{~K}-\Sigma \mathrm{A})$ \\
\hline $\begin{array}{l}1=\text { often indicative of a salt } \\
2=\text { often indicative of adeq } \\
3=\text { often indicative of a fres } \\
\Delta \$=\mid(\mathrm{Na}+\mathrm{K}+\mathrm{Mg}) \text { corr. }+ \\
\Sigma \mathrm{K}=\text { sum of the cations } \\
\Sigma \mathrm{A}=\text { sum of the anions }\end{array}$ & $\begin{array}{l}\text { vater int } \\
\text { ite flush } \\
\text { water i } \\
\Sigma \mathrm{K}-\Sigma_{\mathrm{A}} \\
\mathrm{\Sigma}-\Sigma \mathrm{A}\end{array}$ & $\begin{array}{l}\text { ision (anywhere, anytime) } \\
\mathrm{g} \text { with water of constant composition } \\
\text { rusion (anywhere, anytime) } \\
1 / 2 \mathrm{Cl}|>1,5| \Sigma \mathrm{K}-\Sigma \mathrm{A} \mid \text { (4) }\end{array}$ \\
\hline
\end{tabular}

Table 4

SUBDIVISION OF SUBTYPES INTO 3 CLASSES BASED ON (NA + K + MG) CORRECTED FOR SEA SALT [16] 


\section{Results and discussions}

The factor 1.0716 is equal to $\{(\mathrm{Na}+\mathrm{K}+\mathrm{Mg}) / \mathrm{Cl}\}]$ in $\mathrm{mEq} / \mathrm{L}$ for ocean water [17]. It is assumed that all chloride ions have marine origin [18].

The penetration and elimination of salt water lead to the following empirical ion-exchange equation when the clay is formed and condition $0 \leq \alpha \leq \beta \leq 2$

$$
\begin{gathered}
\mathrm{Ca}^{2+}+[\alpha \mathrm{Na}, \beta \mathrm{K}(1-1 / 2 \alpha-1 / 2 \beta) \mathrm{Mg}]=[\mathrm{Ca}] \text { clay }+ \\
\alpha \mathrm{Na}^{+}+\beta \mathrm{K}^{+}+(1-1 / 2 \alpha-1 / 2 \beta) \mathrm{Mg}^{2+}
\end{gathered}
$$

In the case of the penetration of fresh water, $\mathrm{Ca}$ eliminates the $\mathrm{Na}, \mathrm{K}$ and $\mathrm{Mg}$ ions and the reaction take place from left to right, leading to a surplus of $\{\mathrm{Na}+\mathrm{K}+$ $\mathrm{Mg}$. Reverse reaction occurs when salty water enters the environment. $\mathrm{Na}, \mathrm{K}$, and $\mathrm{Mg}$ do not absorb or desorb simultaneously during freshwater or saltwater intrusions.

Some deviations can occur as follows:

In the following cases, the corrected parameter $\{\mathrm{Na}+$ $\mathrm{K}+\mathrm{Mg}$ \} requires a fairly different interpretation: -dissolving minerals containing $\mathrm{Na}, \mathrm{K}$ and/or Mg such as dolomite, bleached, olivine and serpentine;

-mineralization of biomass;

-leaching, dissolving or draining/infiltration (artificial) of fertilizers;

-dolomitization and other mineral transformations;

-formation of new (synthesis) of minerals containing $\mathrm{Na}$, K and/or Mg;

-biomass synthesis;

-significant atmospheric deposition of gaseous, anthropogenic or volcanic $\mathrm{Cl}$.

Complications 1-3 can produce a surplus of $\{\mathrm{Na}+\mathrm{K}+$ $\mathrm{Mg}\}$, complications 4-7 may cause a $\{\mathrm{Na}+\mathrm{K}+\mathrm{Mg}\}$ deficiency. However, these complications do not make the new less valuable parameter because they may be subject to study.

According to Stuyfzand' water classification, a complete model of waters can be created (fig. 2).

The term mineral water has undergone changes over time, depending on how it was used, which, from a product with curative properties, has turned into a predominantly food product.

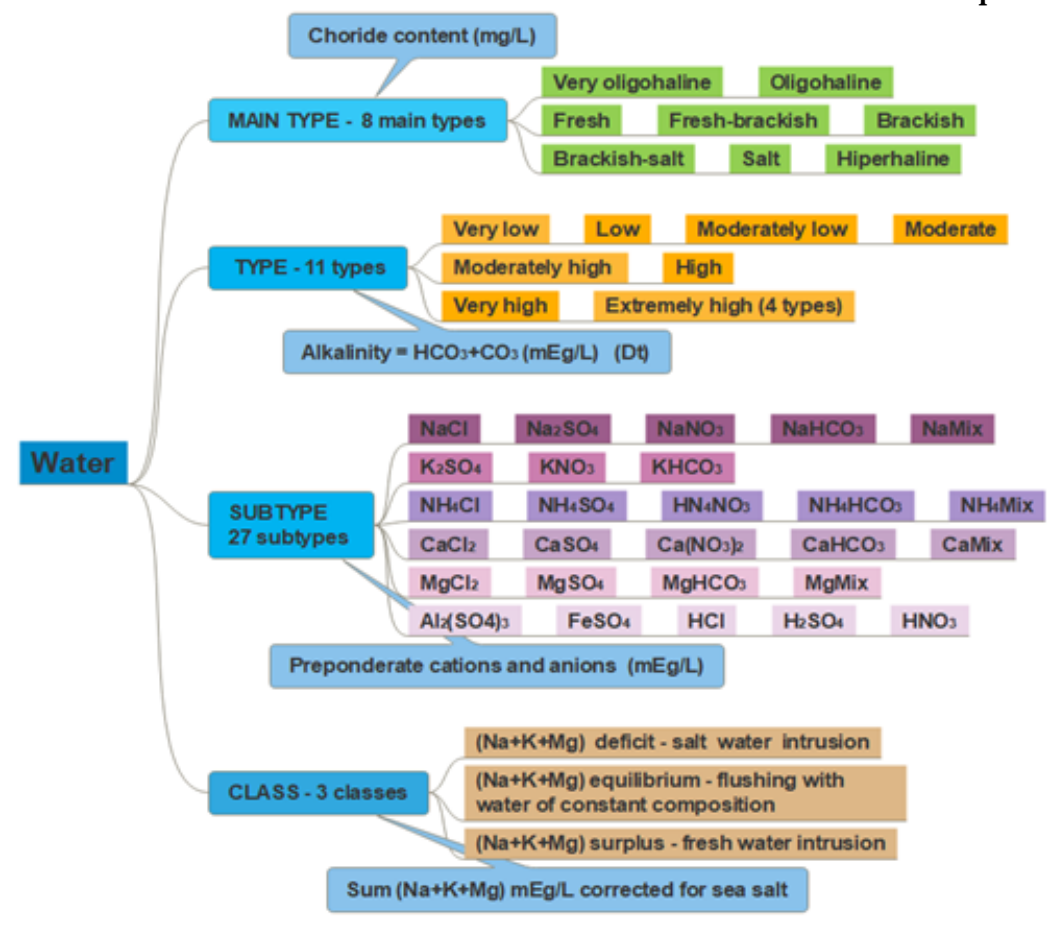

Fig. 2. Diagram of water types
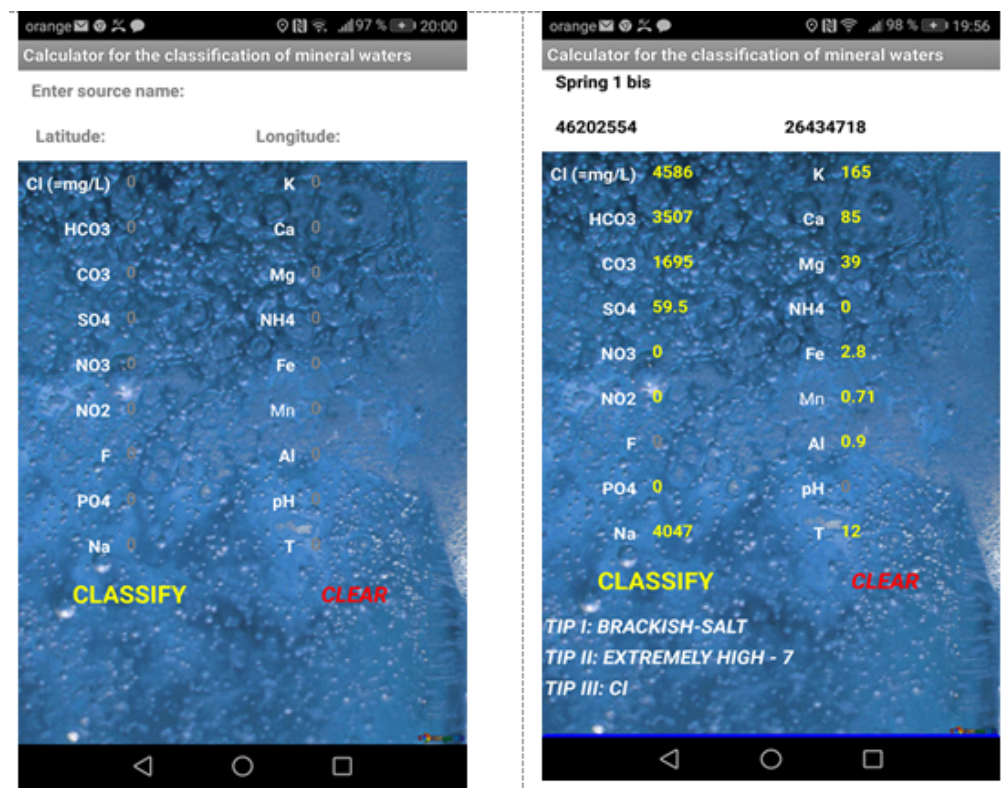

Fig. 3. The interface of the application 


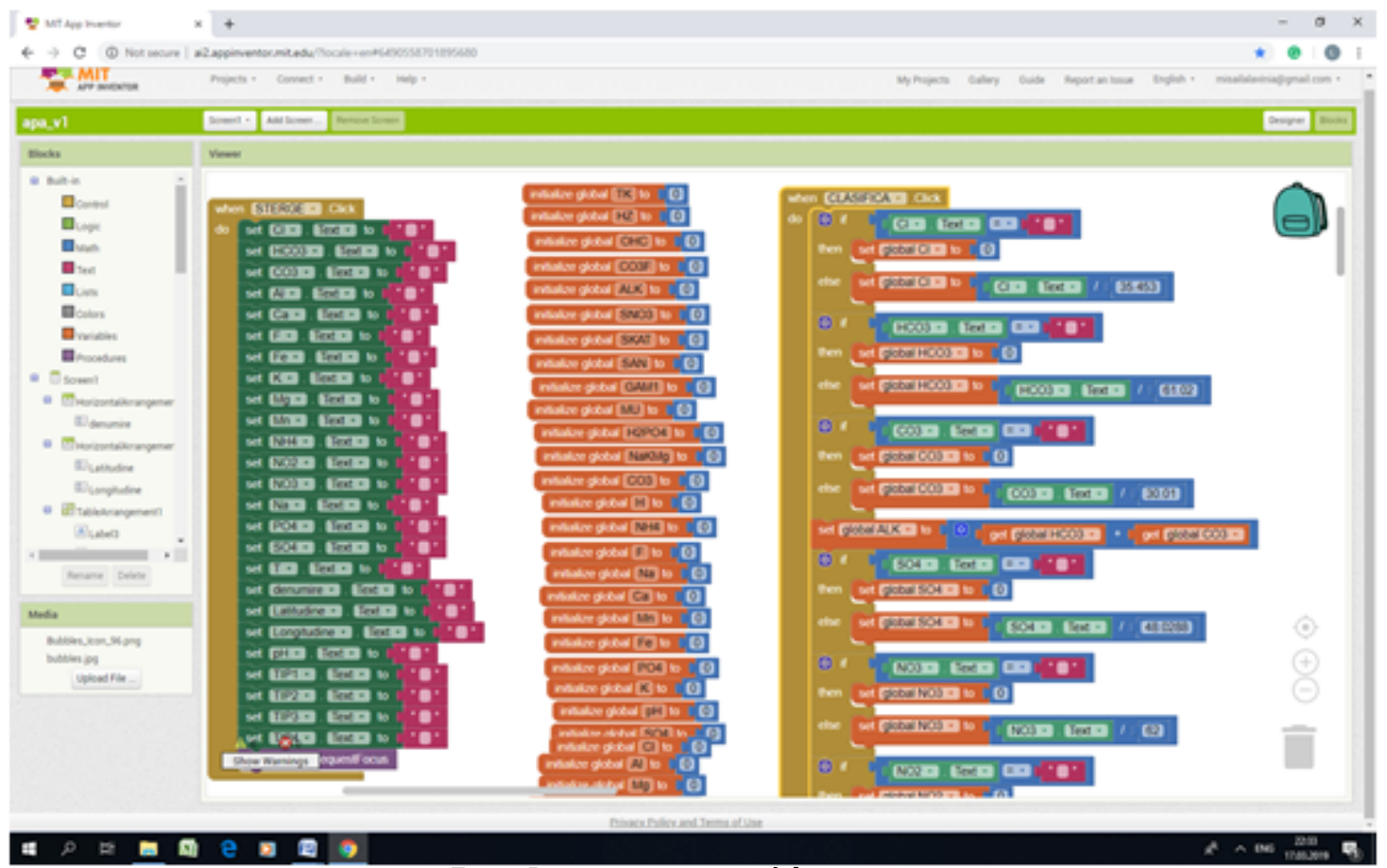

Fig. 4. Print screen image of the program

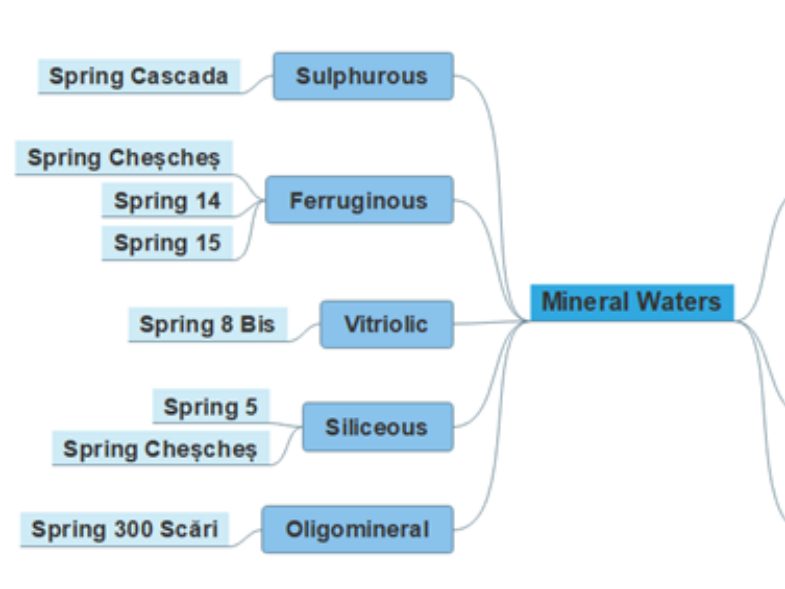

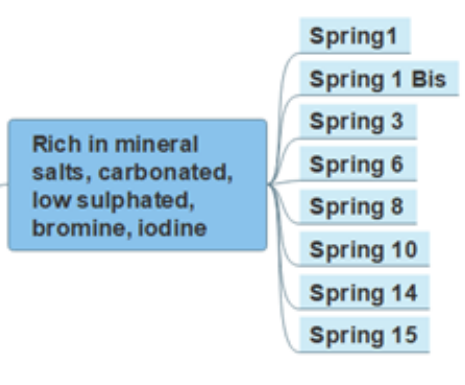

Hypotonic Spring Clunget
Fig. 5. Classification of mineral waters from Slanic-Moldova

\begin{tabular}{|l|l|}
\hline $\begin{array}{l}\text { Alkaline, low } \\
\text { ferruginous, } \\
\text { noncarbonated }\end{array}$ & Spring Sonda 1 \\
\hline Spring Sonda 2 \\
\hline
\end{tabular}

Valued parameters are based on available scientific knowledge and the precautionary principle has also been taken into account; whereas the values in question have been selected to ensure that water intended for human consumption can be safely used throughout its lifetime and thus ensures a high level of health protection.

The model described by Stuyfzand allows the classification of waters according to their composition. The classification of mineral waters according to the weight of certain minerals in their composition is useful for identifying the curative properties of each type of mineral water.

All of the above classifications were used in developing an Android application, Watershed (fig. 3), which classifies and maps any water spring which has a known chemical composition and geographical coordinates.

Watershed is created with MIT App Inventor, an intuitive programming environment that allows the building of fully functional applications for smartphones and tablets. The block-based tool (fig. 4) facilitates the creation of complex, high-impactapplications in much less time than traditional programming environments [19].

By combining the water model of Stuyfzand, which takes into account the concentrations in cations, anions and free substances combined with their limits from Directive 98/83/EC on the exploitation and marketing of natural mineral waters, the following classification for the mineral waters of Slanic-Moldova have been obtained (fig.
5). The modeling has done on a set of data provided by the Institute of Balneology and Physiology from 1957 and 1981.

\section{Conclusions}

The program uses Stuyfzand's water model to build an Android application using an online application development environment, based on a block-based encryption program.

The program classifies the mineral water source by chemical composition and its location on the map using Google's geolocation system. The program allows simultaneous identification of several springs of mineral waters and their location on the map. By synchronizing with the Google maps application, you can create a map of mineral water springs at source as well as at the capture site.

The application created for mineral waters springs from Slanic-Moldova is a facile instrument, ergonomically designed to be used both in outdoor and indoor conditions.

\section{References}

1.DUMITRESCU, C., Dialogue on mineral waters, (in Romanian), Ed. Albatros, Bucharest, 1984, p. 133-137.

2.ALBERTINI, M.C., DACHA, M., TEODORI, L., CONTI, M.E., Drinking mineral waters: Biochemical effects and health implications - The state-of-the-art, International J ournal of Environment and Health, 1, no. 1, 2007, p. 153-169. 
3.PETRACCIA, L., LIBERATI, G., MASCIULLO, S.G., GRASSI, M., FRAIOLI, A., Water, mineral waters and health, Clinical Nutrition, 25, no. 3, 2006, p. 377-385.

4.*** The Mineral Water Market in Romania in 2016, https://trb.ro/ 2016/04/10736-2/ (accessed 10.02.2019).

5.MURARESCU, O., PEHOIU, G., RADULESCU, C., DULAMA, I.D., TEODORESCU, S., STIRBESCU, R.M., MURATOREANU, G., Chemical composition assessment of sulphurous waters, Rev. Chim. (Bucharest), 69, no. 5, 2018, p. 1073-1040.

6.CAPRA, L. MANOLACHE, M., ION, I., STOICA, R., ION, A.C., Validation and optimization of a method for $\mathrm{Sb}$ determination from bottled natural mineral waters by ICP-OES, Rev. Chim. (Bucharest), 69, no. 8, 2018, p. 2102-2106.

7.TUDORAN, G., BALTACEANU, C., Slanic-Moldova and diseases that can be treated (in Romanian), lasi, 1924, p. 7.

8.NICOARÃ, Y., BUSNEA, R., Slanic Moldova. Small tourist guide (in Romanian), Ed. Sport Turism, Bucharest, 1981, p. 18-19.

9. BELCIU, M.C., MOSNEGUTU, E.F., NEDEFF, V., CHIIMUS, A.D., BARSAN, N., FIORE, S., Production capacity of leachate from Bihor landfill, Environmental Engineering and Management J ournal, 15, no. 3, 2016, p. 2057-2062.

10.MUSCALU (PLESCAN), O.M., NEDEFF, V., CHIIMUS, A.D., PARTAL, E., MOSNEGUTU, E., RUSU, I.D., Influence of soil fertilization systems on physical and chemical properties of the soil, Rev. Chim. (Bucharest), 69, no. 11, 2018, p. 3106-3111.
11.TELEKI, N., MUNTEANU, L., SOICESCU, C., TEODOREANU, E., GRIGORE, L., Balneoclimatic cure in Romania (in Romanian), Ed. Sport-Turism, Bucharest, 1984, p. 53-69.

12.MUNTEANU, C., Therapeutic mineral waters, Ed. Balneara, Bucharest, 2013.

13.BERLESCU, E., CHIOREANU, T., COCIASU, E., DENE, A., DINCULESCU, Tr., STEFANESCU, S., TATARANU, I., Directory for references to cure spa, (in Romanian), Ed. Medicala, Bucharest, 1965, p. 172-173.

14.QUATTRINI, S., PAMPALONI, B., BRANDI, M.L., Natural mineral waters: chemical characteristics and health effects, Clinical Cases in Mineral and Bone Metabolism, 13, no. 3, 2017, p. 173-180.

15.***Directive 2009/54/EC of the European Parliament and of the Council of $\mathbf{1 8}$ J une $\mathbf{2 0 0 9}$ on the exploitation and marketing of natural mineral waters.

16.STUYFZAND, P. ., A new hydrochemical classification of water types, Regional Characterization of Water Quality (Proceedings of the Baltimore Symposium, May 1989), International Association of Hydrological Sciences (IAHS) Publications, 1989, 182, p. 89-98.

17.RILEY, J.P., SKIRROW, G., Chemical oceanography, Academic Press, London and New York, 1965;

18.ERIKSSON, E., Composition of atmospheric precipitation. II. Sulfur, chloride, iodine compounds. Bibliography, Tellus, 4, 1952, p. 280303.

19.***http://appinventor.mit.edu/explore/ (accessed 18.02.2019)

Manuscript received: 7.12 .2018 